\title{
Phát triển nhà ở tỉnh Lâm Đồng
}

\section{Housing development: A case study of Lam Dong}

\author{
Nguyễn Bảo Thành ${ }^{1 *}$ \\ ${ }^{1}$ Trường Đại học Mở Thành phố Hồ Chí Minh, Việt Nam \\ *Tác giả liên hệ, Email: thanh.nb@ou.edu.vn
}

THÔNG TIN

DOI: $10.46223 / \mathrm{HCMCOUJS}$.

proc.vi.16.1.1865.2021

Ngày nhận: 7/3/2021

Ngày nhận lại: 30/3/2021

Duyệt đăng: 10/4/2021

\section{Tù khóa:}

nhà ở, phát triển, Lâm Đồng, chính sách

Keywords:

housing, development, Lam Dong, policy

\section{TÓM TẮT}

Nghiên cứu này tìm hiểu về quá trình phát triển nhà của tỉnh Lâm Đồng trong mười năm gần đây (2010-2020). Kết quả khảo sát tại 2 thành phố và 10 huyện tỉnh Lâm Đồng cho thấy địa bàn tỉnh đã có sự phát triển mạnh mẽ về nhà ở sau khi có nhiều chính sách khuyến khích xây dựng từ những năm 2010. Nhiều dự án phát triển nhà thương mại ở đã được hoàn thành và đưa vào sử dụng, nhà ở do người dân tự xây dựng tại một số khu vực tăng cao cả về số lượng và chất lượng. Nhu cầu về nhà ở xã hội tại khu vực đô thị vẫn còn nhiều do sự phát triển, thu hút các thành phần lao động tại khu vực đô thị. Nhưng hầu hết các huyện gặp vấn đề về chậm tiến độ triển khai các dự án phát triển nhà ở; nguồn ngân sách để cho công tác lập quy hoạch cũng như đầu tư hạ tầng kỹ thuật, giải phóng mặt bằng rất hạn chế. Nguồn vốn Trung ương hỗ trợ cho các chương trình hố trợ nhà xã hội cho hộ nghèo, người có công cách mạng về nhà ở phân bổ về chậm ảnh hưởng đến tiến độ thực hiện của đề án được duyệt. Việc khai thác và phát triên nhà ở sinh thái và nghỉ dưỡng Đồng bằng nguôn vốn đầu tư của nhà đầu tư trong và ngoài nước là thiết yếu cho một trong những hướng đi cho tương lai Lâm. Song song với việc này, cơ quan chức năng phải quảng bá thường xuyên các chính sách khuyến khích ưu đãi đầu tư và triển khai các điểm du lịch trọng yếu và khu công nghiệp cho khu vực này.

\section{ABSTRACT}

This study studies the housing development process of Lam Dong province in the past ten years (2010-2020). Survey results in 2 cities and 10 towns of Lam Dong province show that the province has a strong development in housing after having many policies to encourage construction since 2010. Many commercial housing projects have been completed and put into use, the houses built by people in some areas have increased both in quantity and quality. The demand for social houses in urban areas is still high due to the development, attracting all kinds of workers in urban areas. But almost provinces have problems with delayed implementation of the housing development projects; the budget source for planning as well as investment in technical infrastructure and site clearance is very limited. The central government funds supporting programs 
to support social houses for poor households and people with meritorious services in housing have been allocated slowly, affecting the implementation progress of the approved plans. The exploitation as well as development of ecological and convalescence houses by local and foreign investors' investment capital are one of the necessary directions for Lam Dong's future, executing with authority organizations' frequently effective advertisement and implementation subject to the investment encouragement and incentive policies, and deploying main essential travel area and industrial zones for the province.

\section{Giới thiệu}

Phát triển nhà ở là một trong những nội dung quan trọng trong phát triển kinh tế - xã hội. Tỉnh Lâm Đồng đã ban hành nhiều chính sách để thực hiện việc hỗ trợ, tạo điều kiện để người dân có khó khăn về nhà ở để tạo lập được chỗ ở hợp pháp và ổn định, góp phần khuyến khích và thu hút được nhiều nguồn lực tham gia phát triển nhà ở, đồng thời từng bước góp phần tạo nên bộ mặt đô thị văn minh hiện đại.

Nhu cầu về nhà ở luôn là vấn đề được quan tâm của các tầng lớp nhân dân từ đô thị đến nông thôn, đặc biệt là nhu cầu cải thiện chỗ ở của các đối tượng có thu nhập thấp, người có công với cách mạng, công nhân làm việc trong khu công nghiệp, nhà ở của học viên và sinh viên.

Xây dựng và phát triển nhà ở là một trong những yêu cầu cấp bách nhất nhằm đáp ứng nhu cầu về nhà ở của các tầng lớp dân cư với chất lượng, tiện nghi, giá cả phù hợp với điều kiện kinh tế và khả năng thu nhập của từng hộ gia đình, cá nhân..

Mục tiêu của nghiên cứu này nhằm:

- Đánh giá thực trạng nhà ở hiện nay trên địa bàn tỉnh;

- Các vấn đề về phát triển nhà ở cho các tầng lớp;

- Đề xuất các phương án phát triển nhà ở.

Phạm vị nghiên cứu là địa bàn toàn tỉnh Lâm Đồng giai đoạn 2010 - 2020

Phưong pháp nghiên cưu thục hiện:

- Thu thập, xử lý số liệu chính thức từ các cơ quan ban ngành tỉnh Lâm Đồng (Các Sở, UBNN huyện);

- Khảo sát hiện trường.

\section{2. Điều kiện tự nhiên và đơn vị hành chính}

Lâm Đồng có các dạng địa hình khác nhau tạo ra những cảnh quan thiên nhiên phong phú và đa dạng, thuận lợi cho phát triển du lịch, thủy điện. Tuy nhiên địa hình chia cắt mạnh nên gây tốn kém và khó khăn cho xây dựng hệ thống hạ tầng kỹ thuật, làm hạn chế phát triển không gian đô thị và kinh tế xã hội của tỉnh.

Lâm Đồng có khí hậu nhiệt đới gió mùa, nhiệt độ trung bình từ $18-25^{\circ} \mathrm{C}$, thời tiết ôn hòa và mát mẻ quanh năm. Có 2 mùa rõ rệt; mùa mưa từ tháng 5 đến tháng 11 , mùa khô từ tháng 12 đến tháng 4 năm sau.

Những năm 2018-2020, Biến Đổi Khí Hậu (BĐKH) đã tác động trực tiếp đến Đà Lạt. Biểu hiện: vào các mùa mưa, cường suất và tần suất mưa lớn tạo dòng chảy tập trung nhanh, tốc độ lớn 
gây ra hiện tượng ngập lụt cục bộ. Ngược lại, vào mùa khô, lượng nước tại các suối, hồ tự nhiên, hồ thủy lợi giảm đáng kể dẫn đến hiện tượng khô hạn, không đảm bảo việc tưới tiêu, sinh hoạt ở một số địa bàn. Nhà cửa vùng ngoại ô thành phố hoặc nông thôn tự phát chưa tính tới nguy cơ sạt lở.

Tổng dân số của tỉnh Lâm Đồng vào 2019 là 1.296 .906 người, đứng thứ 24 cả nước, và thứ 3 so với vùng Tây Nguyên. Số người sống ở khu vực thành thị là 508.091 người, chiếm 39,18\% và khu vực nông thôn là 788.815 người, chiếm $60,82 \%$ tổng dân số. Dân số nam là 653.074 người, chiếm $50,36 \%$ và nữ là 643.832 người, chiếm $49,64 \%$ tổng dân số.

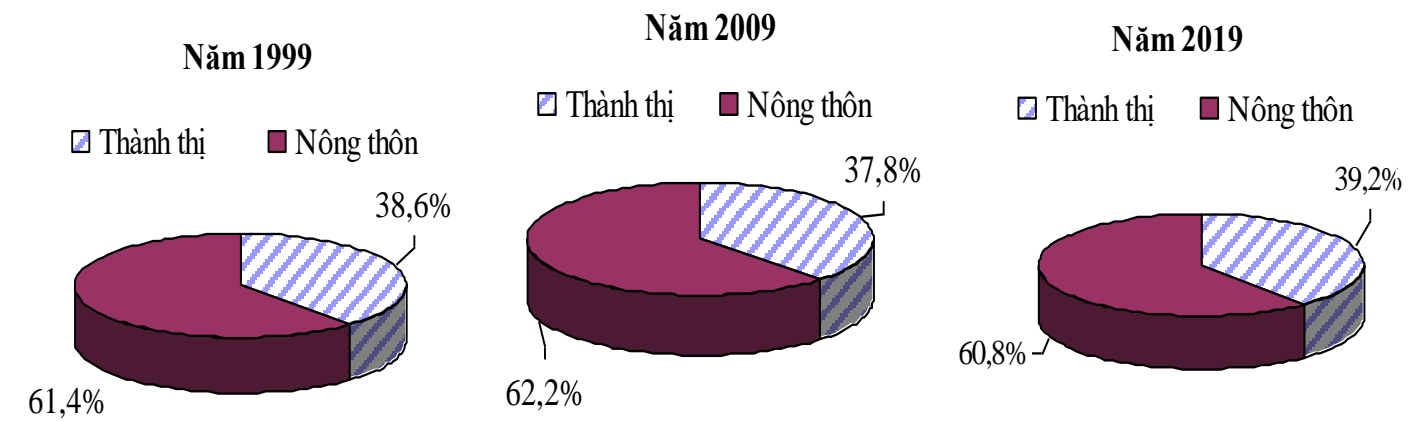

Hình 1. Cơ cấu dân số thành thị và nông thôn các năm

Tỉnh Lâm Đồng có 12 đơn vị hành chính, bao gồm 02 thành phố và 10 huyện được phân chia thành 143 đơn vị hành chính cấp xã bao gồm 17 phường, 14 thị trấn và 112 xã.

\section{Bảng 1}

Các đơn vị hành chính tỉnh Lâm Đồng

\begin{tabular}{|c|c|c|c|c|}
\hline \multirow[t]{2}{*}{ STT } & \multirow[t]{2}{*}{ ĐON VI HÀNH CHÍNH } & \multicolumn{3}{|c|}{ SỐ LỰ̛NG ĐƠN VỊ HÀNH CHÍNH } \\
\hline & & Phường & Thị trấn & Xã \\
\hline 1 & Thành phố Đà Lạt & 12 & & 4 \\
\hline 2 & Thành phố Bảo Lộc & 5 & & 6 \\
\hline 3 & UBND huyện Đức Trọng & & 1 & 14 \\
\hline 4 & UBND huyện Di Linh & & 1 & 19 \\
\hline 5 & UBND huyện Bảo Lâm & & 1 & 13 \\
\hline 6 & UBND huyện Lâm Hà & & 2 & 14 \\
\hline 7 & UBND huyện Đơn Dương & & 2 & 8 \\
\hline 8 & UBND huyện Lạc Dương & & 1 & 5 \\
\hline 9 & UBND huyện Đam Rông & & 1 & 7 \\
\hline 10 & UBND huyện Cát Tiên & & 2 & 7 \\
\hline 11 & UBND huyện Đạ Tẻh & & 1 & 8 \\
\hline 12 & UBND huyện Đạ Huoai & & 2 & 7 \\
\hline \multicolumn{2}{|c|}{ TỔNG CộNG } & 17 & 14 & 112 \\
\hline
\end{tabular}

Nguồn: Cục Thống Kê (2020)

Về cơ cấu nền kinh tế, Lâm Đồng có cơ cấu nền kinh tế gần như mất cân bằng giữa các 
lĩnh vực nông nghiệp, công nghiệp - xây dựng và dịch vụ, cụ thể: Nông lâm thủy sản chiếm 46\%; dịch vụ chiếm $37 \%$ và Công nghiệp - xây dựng chiếm $17 \%$. Điều này cho thấy kế hoạch chuyển dịch cơ cấu kinh tế theo hướng tăng nhanh tỷ trọng giá trị sản phẩm và lao động các ngành dịch vụ, giảm dần tỷ trọng sản phẩm và lao động nông nghiệp chưa được thực hiện triệt để.

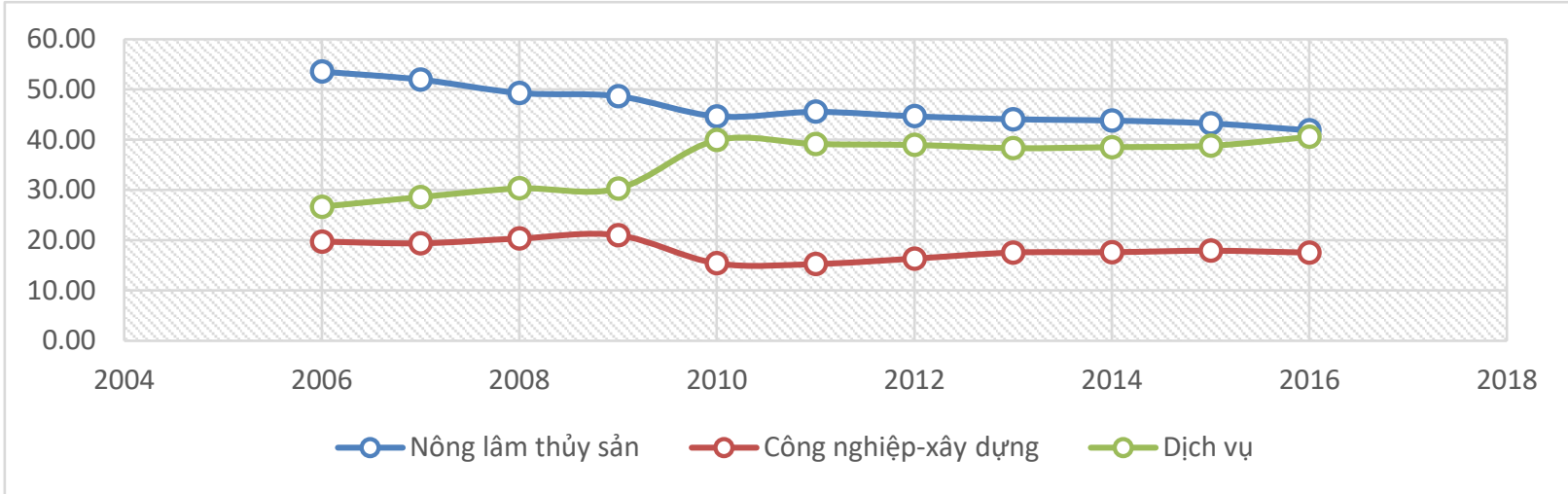

Hình 2. Chuyển dịch cơ cấu kinh tế giai đoạn 2006-2019

Nguồn: Viện Quy hoạch Xây dựng Miền Nam (2018)

Như vậy có thể thấy hoạt động ngành dịch vụ có vai trò quan trọng hơn trong phát triển kinh tế của Tỉnh trong thời gian tới dẫn đến sẽ có ảnh hưởng tới việc thu hút lao động cũng như nâng cao chất lượng nguồn lao động trong tương lai, do đó sẽ có ảnh hưởng tới tương lai phát triển kinh tế và xã hội của tỉnh.

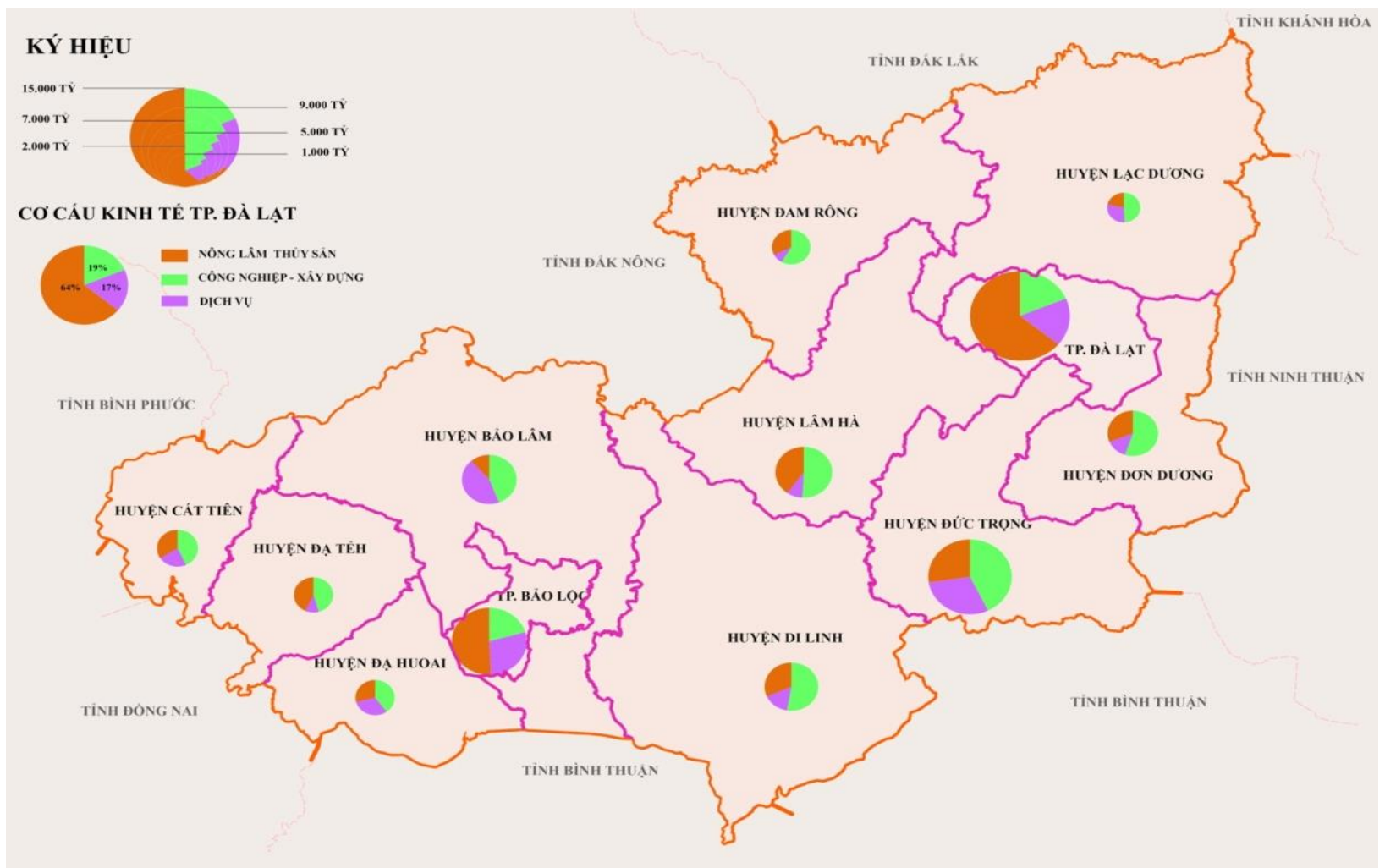

Hình 3. Cơ cấu kinh tế tỉnh Lâm Đồng

Nguồn: Viện Quy hoạch Xây dựng Miền Nam (2018)

\section{Hiện trạng nhà ở trên địa bàn Lâm Đồng}




\subsection{Về số lự̛ng nhà ở}

Năm 2019, tỉnh Lâm Đồng có tổng diện tích sàn nhà ở khoảng $31.313 .963 \mathrm{~m}^{2}$ và khoảng 358.853 hộ (2019), trong đó:

+ Nhà ở đô thị: Tổng số căn nhà ở khu vực đô thị trên địa bàn toàn tỉnh là 148.890 căn (41\%) với tổng diện tích sàn là $14.243 .225 \mathrm{~m}^{2}$;

+ Nhà ở nông thôn: Tổng số căn nhà khu vực nông thôn trên địa bàn toàn tỉnh là 209.964 căn $(59 \%)$ với tổng diện tích sàn là $17.070 .749 m^{2}$.

- Diện tích nhà ở bình quân trên toàn tỉnh (12/2019) là $24,1 \mathrm{~m}^{2}$ sàn/người. Trong đó: khu vực đô thị là $28 \mathrm{~m} 2$ sàn/người, khu vực nông thôn là $21,6 \mathrm{~m}^{2}$ sàn/người.

\section{Bảng 2}

Bảng diện tích nhà ở bình quân đầu người năm 2019

\begin{tabular}{|c|l|c|c|c|c|}
\hline STT & Đơn vị hành chính & Tổng số & Thành thị & Nông thôn vị tính: m & Chênh lệch \\
\hline & Toàn tỉnh & $\mathbf{2 4 , 1}$ & $\mathbf{2 8 , 0}$ & $\mathbf{2 1 , 6}$ & $\mathbf{6 , 3}$ \\
\hline $\mathbf{1}$ & Thành phố Đà Lạt & 27,5 & 27,7 & 25,9 & 1,7 \\
\hline $\mathbf{2}$ & Thành phố Bảo Lộc & 29,3 & 30,4 & 27,4 & 3,0 \\
\hline $\mathbf{3}$ & Huyện Đam Rông & 15,1 & - & 15,1 & - \\
\hline $\mathbf{4}$ & Huyện Lạc Dương & 17,4 & 22,6 & 14,3 & 8,4 \\
\hline $\mathbf{5}$ & Huyện Lâm Hà & 23,1 & 26,6 & 22,1 & 4,5 \\
\hline $\mathbf{6}$ & Huyện Đơn Dương & 23,0 & 27,5 & 21,5 & 6,1 \\
\hline $\mathbf{7}$ & Huyện Đức Trọng & 24,1 & 27,4 & 23,0 & 4,4 \\
\hline $\mathbf{8}$ & Huyện Di Linh & 21,5 & 29,7 & 20,0 & 9,8 \\
\hline $\mathbf{9}$ & Huyện Bảo Lâm & 24,0 & 30,0 & 22,8 & 7,2 \\
\hline $\mathbf{1 0}$ & Huyện Đạ Huoai & 24,1 & 27,3 & 22,1 & 5,1 \\
\hline $\mathbf{1 1}$ & Huyện Đạ Tẻh & 22,3 & 25,0 & 20,8 & 4,2 \\
\hline $\mathbf{1 2}$ & Huyện Cát Tiên & 20,8 & 23,3 & 18,7 & 4,6 \\
\hline
\end{tabular}

Nguồn: Cục thống kê tỉnh Lâm Đồng (2019)

\subsection{Chất lự̛ng nhà ở}

Hiện nay, tỷ lệ nhà ở kiên cố và nhà bán kiên cố tại tỉnh đạt $93,1 \%$; nhà ở thiếu kiên cố và đơn sơ chiếm $6,9 \%$, cụ thể như sau: 


\section{Bảng 3}

Chất lượng nhà ở trên địa bàn tỉnh Lâm Đồng

\begin{tabular}{|c|l|c|c|c|c|c|c|}
\hline \multirow{2}{*}{ STT } & \multirow{2}{*}{ Đơn vị hành chính } & \multicolumn{3}{|c|}{$\begin{array}{c}\text { Tỷ lệ hộ có nhà ở thiếu } \\
\text { kiên cố và đơn sơ }\end{array}$} & \multicolumn{3}{|c|}{$\begin{array}{c}\text { Tỷ lệ hộ có nhà ở kiên cố và } \\
\text { bán kiên cố }\end{array}$} \\
\cline { 3 - 8 } & & Tổng & $\begin{array}{c}\text { Thành } \\
\text { thị }\end{array}$ & $\begin{array}{c}\text { Nông } \\
\text { thôn }\end{array}$ & Tổng số & $\begin{array}{c}\text { Thành } \\
\text { thị }\end{array}$ & $\begin{array}{c}\text { Nông } \\
\text { thôn }\end{array}$ \\
\hline \multirow{2}{*}{} & Toàn tỉnh & $\mathbf{6 , 9}$ & $\mathbf{1 , 9}$ & $\mathbf{1 0 , 5}$ & $\mathbf{9 3 , 1}$ & $\mathbf{9 8 , 1}$ & $\mathbf{8 9 , 5}$ \\
\hline $\mathbf{1}$ & Thành phố Đà Lạt & 1,9 & 1,5 & 5,3 & 98,1 & 98,5 & 94,7 \\
\hline $\mathbf{2}$ & Thành phố Bảo Lộc & 1,7 & 1,2 & 2,5 & 98,3 & 98,8 & 97,5 \\
\hline $\mathbf{3}$ & Huyện Đam Rông & 36,4 & - & 36,4 & 63,6 & - & 63,6 \\
\hline $\mathbf{4}$ & Huyện Lạc Dương & 2,8 & 2,3 & 3,2 & 97,2 & 97,7 & 96,8 \\
\hline $\mathbf{5}$ & Huyện Lâm Hà & 6,7 & 3,2 & 7,7 & 93,3 & 96,8 & 92,3 \\
\hline $\mathbf{6}$ & Huyện Đơn Dương & 6,2 & 3,4 & 7,3 & 93,8 & 96,6 & 92,7 \\
\hline $\mathbf{7}$ & Huyện Đức Trọng & 5,7 & 0,3 & 7,5 & 94,3 & 99,7 & 92,5 \\
\hline $\mathbf{8}$ & Huyện Di Linh & 12,0 & 5,1 & 13,4 & 88,0 & 94,9 & 86,6 \\
\hline $\mathbf{9}$ & Huyện Bảo Lâm & 10,8 & 2,2 & 12,5 & 89,2 & 97,8 & 87,5 \\
\hline $\mathbf{1 0}$ & Huyện Đạ Huoai & 3,7 & 1,3 & 5,2 & 96,3 & 98,7 & 94,8 \\
\hline $\mathbf{1 1}$ & Huyện Đạ Tẻh & 6,8 & 5,8 & 7,4 & 93,2 & 94,2 & 92,6 \\
\hline $\mathbf{1 2}$ & Huyện Cát Tiên & 8,9 & 2,8 & 14,1 & 91,1 & 97,2 & 85,9 \\
\hline
\end{tabular}

Nguồn: Cục Thống Kê (2020)

Hầu hết các hộ dân trong tỉnh đều có nhà ở, chất lượng nhà ở tương đối tốt, phần lớn có khả năng sử dụng lâu dài, chịu được thời tiết chủ yếu là nhà kiên cố hoặc bán kiên cố. Mặc dù nhà nước, các tổ chức, thành phần kinh tế chưa đầu tư mạnh vào lĩnh vực nhà ở nhưng nhà ở trên địa bàn vẫn cơ bản đáp ứng nhu cầu nhà ở cho người dân, nhu cầu về nhà ở chưa đến mức bức xúc như một số vùng hay đô thị khác.

\subsection{Về kiến trúc - Quy hoạch}

Hiện nay, trên địa bàn tỉnh Lâm Đồng, tất cả các đô thị đã có Quy hoạch chung xây dựng được duyệt và một số đồ án Quy hoạch đã và đang được điều chỉnh; còn lại đang trong giai đoạn lập đồ án quy hoạch điều chỉnh. Đặc biệt, Sở Xây dựng đang triển khai tại các địa phương việc điều chỉnh Quy hoạch chung tiệm cận theo địa giới hành chính của đô thị (như: TP. Bảo Lộc, thị trấn Bằng Lăng - huyện Đam Rông, thị trấn Lạc Dương - huyện Lạc Dương, đô thị Liên Nghĩa Liên Khương, huyện Đức Trọng, thị trấn D’Ran - huyện Đơn Dương, thị trấn Cát Tiên - huyện Cát Tiên...).

Nhà ở của nhân dân đa số là tự xây dựng, việc quản lý Quy hoạch - Kiến trúc, cấp giấy phép xây dựng đã đi vào nề nếp, nhận thức của người dân về kiến trúc-thẩm mỹ công trình nhà ở có sự chuyển biến, nên kiến trúc nhà ở phát triển, tạo được bộ mặt kiến trúc, cảnh quan cho đô thị và nông thôn. 
Tại các khu vực đô thị trong tỉnh, đặc biệt là thành phố Đà Lạt, nhà ở hầu như loại hình biệt thự, biệt lập, khách sạn, khu nghỉ dưỡng, du lịch, đủ khoảng không khí và ánh sáng, tạo được không gian sống tiếp xúc với thiên nhiên; công năng, kiểu dáng kiến trúc đẹp, nội ngoại thất hiện đại, hòa hợp với thiên nhiên và đây cũng là điểm khác biệt ở Lâm Đồng nói chung và thành phố Đà Lạt nói riêng với các vùng miền khác trong nước.

Ở khu vực nông thôn, do ảnh hưởng của đô thị, nhiều người dân cũng xây dựng nhà ở theo kiểu dáng nhà biệt thự, biệt lập nhưng quy mô diện tích vừa và nhỏ.

\section{4. Đánh giá chung về thực trạng nhà ở}

\subsection{Kết quả xây nhà ở tăng thêm trong nhũng năm 2010 - 2020}

Chính sách phát triển nhà ở trong 10 năm qua đã phát triển các khu đô thị, khu dân cư mới được hình thành với điều kiện về cơ sở hạ tầng kỹ thuật tương đối hiện đại, tạo diện mạo mới khang trang khu vực đô thị; các dự án nhà ở xã hội đang triển khai, đã từng bước hình thành giải quyết một phần nhu cầu nhà ở dành cho các đối tượng xã hội; các chương trình hỗ trợ về nhà ở cho hộ nghèo, người có công cách mạng, hộ nghèo,...được triển khai có hiệu quả, góp phần cải thiện điều kiện sống, giúp cho các hộ nghèo có nhà ở, ổn định cuộc sống, tạo cơ hội để vươn lên thoát nghèo bền vững, đảm bảo an ninh chính trị, đảm bảo chính sách an sinh xã hội.

\section{Bảng 4}

Kết quả thực hiện Chương trình phát triển nhà ở giai đoạn 2011-2020

\begin{tabular}{|c|l|c|c|c|c|c|}
\hline \multirow{2}{*}{ STT } & \multicolumn{1}{|c|}{ Loại nhà ở } & Kế hoạch & Thực hiện & Tỷ lệ & Số còn lại & Tỷ lệ còn lại \\
\cline { 3 - 7 } & & $\left(\mathrm{m}^{2}\right)$ & $\left(\mathrm{m}^{2}\right)$ & $(\%)$ & $\left(\mathrm{m}^{2}\right)$ & $(\%)$ \\
\hline 1 & Nhà ở thương mại & 837.700 & 497.951 & 59,44 & 339.749 & 40,56 \\
\hline 2 & $\begin{array}{l}\text { Nhà ở người có công với } \\
\text { cách mạng }\end{array}$ & 83.600 & 83.600 & 100 & 0 & 0 \\
\hline 3 & $\begin{array}{l}\text { Nhà ở cho người có thu } \\
\text { nhập thấp }\end{array}$ & 200.000 & 21.601 & 11 & 178.399 & 89,20 \\
\hline 4 & Nhà ở cho người nghèo & 245.660 & 42.514 & 17,31 & 203.146 & 82,69 \\
\hline 5 & Nhà ở công nhân & 24.000 & 0 & 0,00 & 24.000 & 100 \\
\hline 6 & Nhà ở sinh viên & 103.400 & 61.685 & 59,66 & 41.715 & 40,34 \\
\hline 7 & Nhà ở công vụ & 4.620 & 2.480 & 53,68 & 2.140 & 46,32 \\
\hline 8 & Nhà ở giáo viên & 28.330 & 18.487 & 65,26 & 9.843 & 34,74 \\
\hline 9 & Nhà tái định cư & 167.600 & 93.335 & 55,69 & 74.265 & 44,31 \\
\hline 10 & $\begin{array}{l}\text { Nhà ở do người dân tự } \\
\text { dầu tư }\end{array}$ & 10.006 .300 & 10.511 .492 & 105,05 & 0 & 0 \\
\hline
\end{tabular}

Nguồn: Sở Xây Dựng (2019)

Ở giai đoạn 2010-2020 trên địa bàn tỉnh Lâm Đồng phát triển nhà có kết quả như sau:

- Diện tích nhà ở bình quân đầu người toàn tỉnh đến 2019 đạt được $24,1 \mathrm{~m}^{2} /$ người;

- Kêu gọi đầu tư được 03 dự án nhà ở xã hội tham gia đầu tư gồm: Chung cư Ngô Quyền; số 32 Đào Duy Từ; Chung cư nhà ở xã hội Phú Thịnh - số 04 Huyền Trân Công Chúa đã triển 
khai hoàn thành đưa vào sử dụng, với tổng quy mô sử dụng đất $10.388,4 \mathrm{~m}^{2}$, diện tích sàn là 21.601 $\mathrm{m}^{2}$ tương đương $21.601 \mathrm{~m}^{2}$ sàn;

- Đã hoàn thành kết thúc các chương trình hỗ trợ người có công cách mạng về nhà ở theo Đề án 1142/QĐ-UBND ngày 14/6/2013 và Đề án 1434/QĐ-UBND ngày 02/7/2019 với 909 căn.

\subsection{Nhũng tồn tại, hạn chế}

- Nhìn chung, nhiều chỉ tiêu về phát triển nhà ở giai đoạn 2011-2020 chưa đạt kế hoạch đề ra như phát triển nhà ở thương mại, nhà ở tái định cư, nhà ở công nhân, nhà ở cho học sinh, sinh viên.

- Quỹ đất được quy hoạch để dành cho việc phát triển nhà ở xã hội đã được xem xét phê duyệt tại các khu quy hoạch, các dự án phát triển nhà ở thương mại và dự án phát triển đô thị trên địa bàn, nhưng các quỹ đất được dành chủ yếu ở các quy hoạch đô thị nên mà ở đó quỹ đất đền bù giá cao, với đặc thủ đất tại khu vực phát triển công nông nghiệp công nghệ cao nên việc thực hiện đền bù giải phóng mặt bằng khó khăn, kéo dài.

- Việc bồi thường, giải phóng mặt bằng còn gặp khó khăn do đơn giá bồi thường giải phóng mặt bằng chưa phù hợp với thực tế và thấp so với các địa phương lân cận; còn thiếu sự đồng thuận của người dân trong công tác bồi thường giải phóng mặt bằng...

- Có sự mất cân đối về số lượng, cơ cấu nhà ở giữa khu vực đô thị và khu vực nông thôn: nhà ở khu vực đô thị phát triển nhanh, với chất lượng nhà ở tốt hơn, đa dạng hơn ở khu vực nông thôn.

- Ở khu vực đô thị, nhiều khu dân cư quy hoạch đồng bộ mới được hình thành, nhà cửa mới xây đa phần đẹp và hiện đại, góp phần tạo nên những bộ mặt mới cho khu vực đô thị, tập trung ở thành phố Đà Lạt, Bảo Lộc, Đức Trọng. Bên cạnh đó vẫn còn nhiều vấn đề bất cập như việc kiểm soát xây dựng nhà ở theo thiết kế đô thị tại các khu vực quy hoạch mới; nhiều khu vực trong đô thị tồn tại theo hiện trạng chưa được quy hoạch, đường giao thông nhỏ hẹp, thiếu kết nối, manh mún, hệ thống hạ tầng kỹ thuật chưa đồng bộ, nhiều khu vực đô thị nhưng người dân xây dựng nhà ở như ở nông thôn (xây chuồng trại chăn nuôi gia súc, gia cầm), làm mất mỹ quan cũng như ảnh hưởng đến môi trường sống khu vực đô thị, nhất là đối với những khu vực đô thị mới hình thành do nâng cấp, dựa trên nền tảng khu dân cư nông thôn hiện hữu, hệ thống hạ tầng kỹ thuật chưa đầy đủ và đồng bộ.

- Chất lượng xây dựng nhà ở nông thôn đã có nhiều chuyển biến tích cực, ngày càng có nhiều ngôi nhà quy mô lớn, kiên cố và khang trang được xây dựng. Tuy nhiên, không đồng đều giữa các vùng; tình trạng nhà ở, điều kiện hạ tầng kỹ thuật, môi trường sống của các hộ dân ở nông thôn tại một số nơi, một số vùng nhất là ở vùng sâu, vùng xa, vẫn chưa đáp ứng được yêu cầu đặt ra.

- Đối với việc phát triển nhà ở xã hội tại đô thị:

+ Hiện nay, tại địa phương thiếu quỹ đất sạch, mà hầu hết là các quỹ đất dành để đầu tư xây dựng nhà ở xã hội đều phải thực hiện công tác bồi thường, hỗ trợ, giải phóng mặt bằng, đầu tư hạ tầng kỹ thuật mới triển khai đầu tư xây dựng. Việc giải tỏa bồi thường giải phóng mặt bằng rất khó khăn do giá cả tăng đột biến trong việc đền bù, nên dẫn đến thời gian kéo dài, chậm triển khai đầu tư xây dựng. Mặt khác, kinh phí đền bù giải phóng mặt bằng, đầu tư hạ tầng kỹ thuật của nhà nước hết sức khó khăn, nên phải kêu gọi nhà đầu tư cùng phối hợp, hỗ trợ triển khai thực hiện. Giá thành căn hộ sẽ tăng khi không được nhà nước hỗ trợ về kinh phí đền bù giải phóng mặt bằng (nhà đầu tư phải phân bổ kinh phí đền bù giải phóng mặt bằng vào giá thành căn hộ) chính vì vậy, sẽ ảnh hưởng đến việc người thu nhập thấp mà phải mua căn hộ giá cao; 
+ Tại các dự án khu dân cư, dự án phát triển đô thị, dự án phát triển nhà ở đã có quyết định chủ trương đầu tư nhưng tiến độ thực hiện của các chủ đầu tư chậm dẫn đến việc quỹ đất $20 \%$ trong các dự án này chưa được phát huy (dự án Khu dân cư số 1 , phường 8 , thành phố Đà Lạt; dự án Khu dân cư số 5, Phường 4 - Đà Lạt; Dự án xây dựng Khu dân cư số 6 Trại Mát, phường 11 thành phố Đà Lạt) dẫn đến việc phát triển nhà ở xã hội chưa đạt chỉ tiêu đề ra.

- Việc phát triển nhà ở cho công nhân tại các khu công nghiệp, cụm công nghiệp: Qua khảo sát thực tế thì nhu cầu của công nhân về nhà ở tại các khu công nghiệp trên địa bàn tỉnh chưa cấp thiết và theo ý kiến của địa phương thì công nhân, người lao động tại Khu công nghiệp chủ yếu là người địa phương, làm việc theo thời vụ, không ổn định nên số lượng có nhu cầu nhà ở không nhiều và chưa cấp thiết nên việc đầu tư nhà ở cho công nhân triển khai chậm dẫn đến chưa đầu tư theo kế hoạch đề ra.

- Đối với các dự án nhà ở thương mại: Phần lớn các dự án có tiến độ thực hiện chậm là do gặp khó khăn trong công tác bồi thường giải phóng mặt bằng. Đồng thời, có một số nhà đầu tư sau khi có chấp thuận chủ trương dự án không thực hiện triển khai vì năng lực tài chính không đảm bảo để thực hiện dự án. Các dự án đầu tư hạ tầng kỹ thuật xong nhưng chậm triển khai xây dựng nhà để bán.

- Nhà ở cho các đối tượng hộ nghèo, gia đình người có công với cách mạng tuy đã được UBND tỉnh, các cấp các ngành tích cực chỉ đạo, tổ chức thực hiện tốt, song tiến độ thực hiện ở một số chương trình vẫn còn chậm. Nguồn lực thực hiện chưa đầy đủ và còn chậm được bố trí. Nhiều nơi, nhiều hộ nghèo, người có công với cách mạng khó khăn về nhà ở có nhu cầu cải thiện nhà ở thực sự cần thiết nhưng các nguồn lực hỗ trợ không kịp thời, một số hộ dân không có đất, dẫn đến thiệt thòi cho người dân không được hưởng chính sách của chương trình này.

- Nhà ở tái định cư:

+ Trong thời gian qua, UBND tỉnh, UBND các huyện, thành phố Đà Lạt, Bảo Lộc và chủ đầu tư được giao đất thu hồi để thực hiện dự án các dự án trọng điểm mà tập trung chủ yếu trên địa bàn thành phố Đà Lạt, Bảo Lộc. UBND tỉnh đã chú trọng quan tâm đến việc thực hiện chính sách tái định cư; chỉ đạo thực hiện đầu tư xây dựng các khu tái định cư; áp dụng nhiều phương thức trong việc thực hiện tạo lập quỹ nhà, đất để phục vụ tái định cư;

+ Tuy nhiên, thực tế cho thấy việc triển khai đầu tư xây dựng các khu tái định cư còn chậm và quỹ đất phục vụ cho việc bố trí tái định cư còn thiếu, không có đủ quỹ nhà, đất để phục vụ tái định cư tương xứng với kế hoạch thu hồi đất để thực hiện các dự án, việc tái định cư cho các hộ gia đình bị thu hồi đất thực hiện còn chắp vá và thụ động.

\subsection{Nguyên nhân của nhũng hạn chế, tồn tại}

\subsubsection{Nguyên nhân khách quan}

+ Hiện nay, vẫn còn những quy định chưa rõ ràng, chưa khuyến khích các Nhà đầu tư tham gia phát triển nhà ở, làm cho quan hệ cung - cầu về nhà ở vẫn còn mất cân đối và nhiều bất cập. Việc phát triển nhà ở trên địa bàn tỉnh tuy đã được quan tâm, nhưng chưa được quan tâm và đầu tư của nhà nước cũng như của các tổ chức, thành phần kinh tế. Nhà ở chủ yếu là do người dân tự xây dựng và loại hình nhà ở riêng lẻ chiếm tỷ lệ gần như tuyệt đối, có rất ít các dự án phát triển nhà ở được đầu tư hoàn thành trong giai đoạn;

+ Chương trình, kế hoạch phát triển nhà trên địa bàn tỉnh xây dựng về các chỉ tiêu đưa ra chưa sát với thực tế của từng địa phương trên địa bàn tỉnh dẫn đến định hướng các chỉ tiêu cao;

+ Chính sách pháp luật về đất đai có nhiều thay đổi, tình hình thị trường có nhiều đột biến, 
giá cả tăng nhanh trong thời gian ngắn, nhất là thị trường Đà Lạt dẫn đến việc xây dựng giá đất đền bù giải phóng mặt bằng chưa có cơ sở. Việc thẩm định giá đất thiếu cơ sở thông tin về giá thị trường nên kéo dài về thời gian khảo sát, điều chỉnh hồ sơ, thẩm định hồ sơ cho thuê đất, giao đất nên không thể triển khai việc đền bù để giao đất, cho thuê đất để nhà đầu tư thực hiện đầu tư dự án;

+ Công tác quy hoạch chi tiết xây dựng đã được chú trọng, nhiều đồ án được thiết lập để làm cơ sở cho chính quyền địa phương các cấp có cơ sở pháp lý cần thiết để quản lý xây dựng. Tuy nhiên, do việc phát triển kinh tế từng khu vực, từng địa phương chênh lệch nên việc đầu tư phát triển cơ sở hạ tầng kỹ thuật để hình thành hệ thống khung cho việc phát triển các khu dân cư gặp nhiều khó khăn, dẫn đến nhiều đồ án quy hoạch được phê duyệt nhưng chậm được thực hiện gây khó khăn cho việc đầu tư xây dựng của các tổ chức và cá nhân;

+ Do địa hình của thành phố Đà Lạt có sự chênh lệch lớn, nên đầu tư xây dựng công trình cao hơn do phải san ủi mặt bằng, xây dựng kè nền móng, có các giải pháp về kết cấu nên dẫn đến chi phí đầu tư cao. Bên cạnh đó có các yêu cầu về quy hoạch kiến trúc, bảo vệ cảnh quan môi trường nên hệ số sử dụng đất thấp (mật độ xây dựng không cao nên hiệu quả vốn đầu tư khi đầu tư vào các dự án không cao);

+ Nguồn vốn đầu tư, hỗ trợ của nhà nước còn hạn chế, chưa đáp ứng nhu cầu, nhất là nguồn vốn hỗ trợ nhà ở cho người nghèo, người có công cách mạng và vốn bố trí cho công tác lập quy hoạch, đầu tư hạ tầng kỹ thuật và cho quỹ phát triển nhà ở của tỉnh còn khó khăn;

+ Nguồn vốn của quỹ phát triển nhà ở để đầu tư cho nhà ở xã hội còn khó khăn, không huy động được từ nguồn trích tiền sử dụng đất của các dự án phát triển nhà ở thương mại và khu đô thị mới, vốn Trung ương, vốn ODA và trái phiếu chính phủ; Nguồn vốn từ các thành phần kinh tế cũng gặp khó khăn trong huy động, vay vốn ưu đãi;

+ Quản lý nhà nước về đất đai và quy hoạch chưa theo kịp nhu cầu phát triển của xã hội đặc biệt tại các khu vực tiềm năng phát triển du lịch ven biển dẫn đến người dân tự ý phân lô bán nền, đưa thông tin giả để đẩy giá trị bất động sản. Việc chuyển mục đích sử dụng đất chưa bám sát quy hoạch chi tiết xây dựng được duyệt.

\subsubsection{Nguyên nhân chủ quan}

+ Công tác quản lý nhà nước, kiểm tra, thanh tra, xử lý vi phạm về đất đai, xây dựng chưa thường xuyên, kiên quyết, có lúc, có nơi còn buông lỏng; việc phối hợp giữa các cơ quan, đơn vị, địa phương chưa đồng bộ, hiệu quả; các địa phương chưa quan tâm, chú trọng quy hoạch chỉnh trang khu dân cư. Công tác rà soát, ban hành các quy định, cơ chế, chính sách và tháo gỡ khó khăn, vướng mắc trong thu hút đầu tư phát triển nhà ở hiệu quả chưa cao; việc thu hút các nguồn lực của xã hội tham gia đầu tư phát triển nhà ở trên địa bàn tỉnh còn nhiều khó khăn;

+ Các địa phương chưa nắm bắt nhu cầu, nguyện vọng của người dân về nhà ở, đất ở, chưa chủ động rà soát lại nhu cầu đất ở nông thôn để xây dựng cơ chế chính sách giao đất ở cho một số đối tượng chính sách xã hội. Hậu quả là người dân tự phân lô bán nền trên đất nông nghiệp, xây dựng trái phép;

+ Việc phối hợp giữa các sở, ngành và chủ đầu tư trong đền bù giải phóng mặt bằng còn chưa kịp thời, chặt chẽ, trong đó tâm lý nhà đầu tư chưa thực sự quyết liệt khi đã được chấp thuận địa điểm đầu tư, chủ trương đầu tư. Ngoài ra, một số chủ đầu tư vi phạm về quy hoạch xây dựng, quản lý đất đai, chậm đưa dự án vào triển khai nên bị dừng dự án;

+ Nguồn lực để đầu tư phát triển nhà ở xã hội, nhà ở tái định cư tại khu vực đô thị còn thiếu, chưa được tỉnh bố trí nguồn vốn để đầu tư phát triển. Nguồn vốn bố trí cho giải phóng mặt 
bằng để có đất sạch để kêu gọi nhà đầu tư xây dựng dự án nhà ở xã hội, nhà ở tái định cư chưa được bố trí. Chủ yếu là tranh thủ nguồn vốn tạm ứng của nhà đầu tư để thực hiện đền bù giải phóng mặt bằng nên dẫn đến các dự án triển khai phụ thuộc nhà đầu tư;

+ Cơ chế ưu đãi cho nhà đầu tư khi xây dựng nhà ở xã hội ngày càng nhiều nhưng chưa đủ mạnh để thu hút nhà đầu tư quan tâm, đầu tư vào lĩnh vực có lợi nhuận thấp; quá trình thiết lập dự án và xây dựng nhà ở tương đối phức tạp và tốn nhiều thời gian, công sức.

\section{Bàn luận và vấn đề còn tồn tại}

Trong giai đoạn 2010-2020, khu vực nông thôn đã phát triển mạnh mẽ về nhà ở. Nhiều dự án phát triển nhà ở đã được hoàn thành và đưa vào sử dụng, nhà ở do người dân tự xây dựng tại một số khu vực tăng cao cả về số lượng và chất lượng. Nhu cầu về nhà ở xã hội tại khu vực đô thị vẫn còn nhiều do sự phát triển, thu hút các thành phần lao động tại khu vực đô thị. Bên cạnh một số khu vực có sự phát triển mạnh về nhà ở, một số khu vực khác tốc độ phát triển nhà ở còn chậm, một số chỉ tiêu chưa đạt trong mục tiêu đề ra.

Nguyên nhân tác động tới phát triển nhà ở trên địa bàn tỉnh trong thời gian qua, cụ thể như: phát triển kinh tế chưa đồng đều giữa các khu vực; vẫn còn một bộ phận hộ dân cư đang sống trong các ngôi nhà có diện tích chật hẹp, nhất là ở huyện Đam Rông và huyện Lạc Dương có diện tích nhà ở bình quân đầu người còn khá thấp; số lượng nhà ở cho công nhân lao động tại các khu, cụm công nghiệp còn ít, chưa đáp ứng được yêu cầu; nhà ở dành cho các đối tượng chính sách xã hội khác được hoàn thành rất ít so với nhu cầu nhà ở xã hội.

Tình hình thực hiện các chương trình hỗ trợ nhà ở và tiến độ đầu tư xây dựng các khu dân cư, khu đô thị mới, nhà ở xã hội, nhà ở cho người nghèo, người có công cách mạng và một số công trình hạ tầng kỹ thuật đô thị còn chậm, chưa đáp ứng yêu cầu; các loại nhà ở tái định cư, nhà ở công nhân, nhà ở công vụ ít được triển khai; quỹ đất sạch dành cho phát triển nhà ở xã hội còn nhiều khó khăn; một số cơ chế, chính sách và việc thu hút, kêu gọi các thành phần kinh tế tham gia đầu tư phát triển nhà ở, xây dựng hạ tầng các khu dân cư chưa hiệu quả, còn khó khăn, trở ngại.

Việc áp dụng các chính sách bồi thường giải phóng mặt bằng chưa kịp thời, hiệu quả dẫn đến việc khiếu nại, khiếu kiện làm ảnh hưởng đến tiến độ triển khai các dự án phát triển nhà ở; nguồn ngân sách để cho công tác lập quy hoạch cũng như đầu tư hạ tầng kỹ thuật, giải phóng mặt bằng rất hạn chế (hầu như địa phương nào cũng gặp khó khăn về vấn đề này). Nguồn vốn Trung ương hỗ trợ cho các chương trình hỗ trợ hộ nghèo, người có công cách mạng về nhà ở phân bổ về chậm ảnh hưởng đến tiến độ thực hiện của đề án được duyệt.

Việc xây dựng mô hình "Làng đô thị xanh" là một giải pháp cần được xem xét, nghiên cứu để áp dụng rộng rãi ở tỉnh Lâm Đồng nói riêng, khu vực Tây Nguyên và các vùng khác có các yếu tố điều kiện tự nhiên, văn hóa, đặc điểm kinh tế - xã hội tương đồng. Hình 2 là mô hình tổ chức sản xuất nông nghiệp, môi trường ở theo nguyên tắc cân bằng môi trường duy trì mực nước ngầm, đảm bảo đa dạng sinh học, hấp thụ khí $\mathrm{CO} 2$, cung cấp $\mathrm{O} 2$, sử dụng năng lượng tái tạo...phát triển bền vững. 


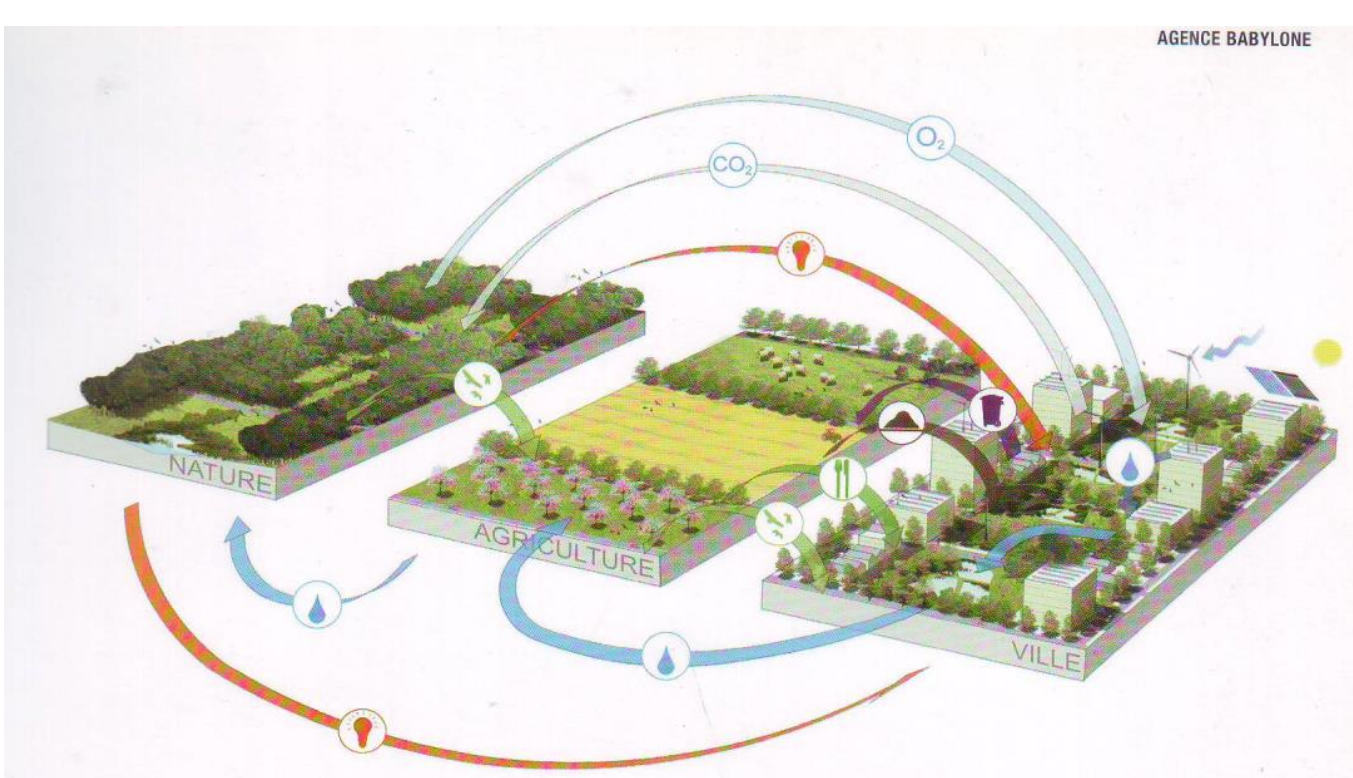

Hình 4. Mô hình "Làng đô thị xanh"

Nguồn: Trung (2016)

\section{Kết luận}

Tại Lâm Đồng nhà ở xã hội còn rất thiếu nguồn cung trầm trọng; đầu tư Nhà ở xã hội chỉ mới đạt được một phần ba so với mục tiêu phát triển nhà ở của tỉnh. Nhà ở thương mại chậm tiến độ so với các dự án đầu tư đã phê duyệt nên không đáp ứng được những người có khả năng mua được. Tuy nhiên, hiện nay có nhiều dự án tỉnh đã kêu gọi đầu tư nhưng chưa hấp dẫn các nhà đầu tư bất đông sản vì các quy định về xây dựng như: chiều cao tầng, mật độ xây dựng, hệ số sử dụng đất thấp nên đã hạn chế lợi nhuận của nhà đầu tư. Vì vậy, nguồn cung nhà thương mại chỉ có ở khu vực thành phố Đà Lạt và Bảo Lộc. Chất lượng nhà ở tại khu vực nông thôn còn thấp chủ yếu là nhà cấp 4 , chỉ có vùng đô thị thì chất lượng nhà ở còn đồng đều. Nguồn cung cấp nhà chung cư đang thấp so với nhu cầu.

Việc khai thác và phát triên nhà ở sinh thái và nghỉ dưỡng Đồng bằng nguôn vốn đầu tư của nhà đầu tư trong và ngoài nước là thiết yếu cho một trong những hướng đi cho tương lai Lâm. Song song với việc này, cơ quan chức năng phải quảng bá thường xuyên các chính sách khuyến khích ưu đãi đầu tư và triển khai các điểm du lịch trọng yếu và khu công nghiệp cho khu vực này.

\section{Tài liệu tham khảo}

Cục Thống Kê. (2020). Niên giám thống kê tỉnh Lâm Đồng năm 2019 [Lam Dong Statistical Yearbook 2019]. Retrieved May 10, 2019, from http://cucthongke.lamdong.gov.vn/Default.aspx?Act=10\&IDNews=956

Sở Xây Dựng. (2019). Đánh giá Chwơng trình phát triển nhà ở trên địa bàn tỉnh Lâm Đồng giai đoạn 2011-2020 [Assessment of Housing Development Program in Lam Dong Province for the period 2011-2020]. Uỷ Ban Nhân Dân tỉnh Lâm Đồng, Đà Lạt.

Trung, L. Q. (2016). Đà Lạt với mô hình thí điểm "Làng đô thị Xanh" [Dalat with the pilot model "Green Urban Village"]. Retrieved May 15, 2019, from Tạp chí Kiến trúc Việt Nam website: http://kientrucvietnam.org.vn/da-lat-voi-mo-hinh-thi-diem-lang-do-thi-xanh/

Viện Quy hoạch Xây dựng Miền Nam. (2018). Quy hoạch xây dưng vùng tỉnh Lâm Đồng 
[Regional construction planning of Lam Dong province]. Lâm Đồng, Vietnam: Bộ Xây Dựng.

Ủy ban nhân dân tỉnh Lâm Đồng. (2013). Quyết định số 1142/QĐ-UBND ngày 14 tháng 6 năm 2013 phê duyệt đề án hố trợ người có công với cách mạng về nhà ở trên địa bàn tỉnh Lâm Đồng [Decision 1142/QD-UBND dated 14 June 2013 approved the project to support people with meritorious services to the housing revolution in Lam Dong province]. Retrieved May 20, 2019, from https://thuvienphapluat.vn/van-ban/Bat-dong-san/Quyet-dinh-so-1142-QDUBND-2013-ho-tro-nguoi-co-cong-voi-cach-mang-ve-nha-o-Lam-Dong-215783.aspx

Ủy ban nhân dân tỉnh Lâm Đồng. (2013). Quyết định số 1434/QĐ-UBND ngày 2 tháng 7 năm 2019 ban hành đề án hồ trợ nhà ở cho người có công với cách mạng giai đoạn 2 trên địa bàn tỉnh Lâm Đồng [Decision 1434/QD-UBND dated 2 July 2019 issue housing support projects for people with meritorious services to the revolution phase 2 in the province of Lam Dong]. Retrieved May 25, 2019, from https://thuvienphapluat.vn/van-ban/Bat-dong-san/Quyetdinh-1434-QD-UBND-2019-ve-De-an-ho-tro-nha-o-cho-nguoi-co-cong-voi-cach-mangLam-Dong-418226.aspx 